\title{
Effects of Ocean Ecosystem on Marine Aerosol-Cloud Interaction
}

\author{
Nicholas Meskhidze ${ }^{1}$ and Athanasios Nenes ${ }^{2,3}$ \\ ${ }^{1}$ Department of Marine, Earth and Atmospheric Sciences, North Carolina State University, Raleigh, NC 27695, USA \\ ${ }^{2}$ School of Earth and Atmospheric Sciences, Georgia Institute of Technology, Atlanta, GA 30332, USA \\ ${ }^{3}$ School of Chemical and Biomolecular Engineering, Georgia Institute of Technology, Atlanta, GA 30332, USA \\ Correspondence should be addressed to Nicholas Meskhidze, nmeskhidze@ncsu.edu
}

Received 1 March 2010; Accepted 12 May 2010

Academic Editor: Charles R. McClain

Copyright ( $) 2010$ N. Meskhidze and A. Nenes. This is an open access article distributed under the Creative Commons Attribution License, which permits unrestricted use, distribution, and reproduction in any medium, provided the original work is properly cited.

Using satellite data for the surface ocean, aerosol optical depth (AOD), and cloud microphysical parameters, we show that statistically significant positive correlations exist between ocean ecosystem productivity, the abundance of submicron aerosols, and cloud microphysical properties over different parts of the remote oceans. The correlation coefficient for remotely sensed surface chlorophyll $a$ concentration ([Chl-a]) and liquid cloud effective radii over productive areas of the oceans varies between -0.2 and -0.6 . Special attention is given to identifying (and addressing) problems from correlation analysis used in the previous studies that can lead to erroneous conclusions. A new approach (using the difference between retrieved AOD and predicted sea salt aerosol optical depth, $\mathrm{AOD}_{\text {diff }}$ ) is developed to explore causal links between ocean physical and biological systems and the abundance of cloud condensation nuclei $(\mathrm{CCN})$ in the remote marine atmosphere. We have found that over multiple time periods, $550 \mathrm{~nm} \mathrm{AOD}$ diff (sensitive to accumulation mode aerosol, which is the prime contributor to CCN) correlates well with [Chl- $a$ ] over the productive waters of the Southern Ocean. Since [Chl- $a$ ] can be used as a proxy of ocean biological productivity, our analysis demonstrates the role of ocean ecology in contributing CCN, thus shaping the microphysical properties of low-level marine clouds.

\section{Introduction}

Aerosols influence the planetary radiation balance directly by scattering and absorbing sunlight, and indirectly by modifying cloud microphysical properties [1-4]. Marine aerosols are particularly important, as they contribute considerably to the global aerosol load, are emitted from a large surface area, and have an ability to strongly influence reflective properties and lifetime of marine stratiform clouds [5]. Marine aerosols could be especially important for understanding the cloudmediated effects of aerosols on climate, because cloud properties are most sensitive to the addition of particles when the background concentration is low [6]. Factors that regulate the concentration of marine aerosols, and thus the reflectivity of low-level marine clouds, can strongly affect the whole climate system $[7,8]$. Cloud droplet number concentration (CDNC) over the remote oceans ranges from a few tens per $\mathrm{cm}^{3}$ in biologically inactive regions (seasons) to a few hundred per $\mathrm{cm}^{3}$ under biologically active conditions [9]. Despite recognizing their crucial role, the source strength and chemical composition of marine aerosols remain poorly quantified $[10,11]$.

Aerosols over the remote oceans consist of a mixture of sea salt particles, organics, and sulfates from the oxidation of biogenic dimethyl sulfide (DMS), with certain contribution from mineral dust and smoke from wildfires [9]. Sea salt is a major component of marine aerosol over regions with high wind speeds and/or when other aerosol sources are weak [12-16]. In addition to sea salt, the biological sulfur cycle has also been proposed as a major source of CCN over biologically active regions of the oceans $[17,18]$. In recent years, significant abundances of organic carbon (OC) aerosols (in addition to sea salt and DMS oxidation products) have been identified in marine environments [19-23]. The concentrations of marine-source OC aerosols are particularly high over regions of enhanced oceanic biological activity [24]. These organic aerosols have been proposed to have two distinctly different sources which can be broadly classified as primary and secondary [25]. Bubble bursting processes that emit sea salt aerosols into marine boundary layer also 
transfer marine primary organic matter (POM), which is composed of biogenic secretions and bacterial/viral debris [24, 26-29]. Secondary organic aerosols (SOAs) over remote marine regions were proposed to be formed from phytoplankton emitted different types of biogenic volatile organic compounds (BVOCs) [30-34]. Because of their enhanced fine-mode concentration and surface active nature, these organic particles could act synergistically with the established mechanisms of DMS and sea salt, influencing both number concentration and CCN activity of remote marine aerosols $[24,32,35]$. Overall, analyses of marine aerosol chemical composition show that over the productive waters of the ocean the majority of submicron mass of sea spray aerosols can be organic [24, 36-38].

The importance of marine biogenic source contribution to $\mathrm{CCN}$ number has motivated numerous studies (using remote sensing products, in situ measurements or modeling) to examine the relationship between ocean productivity and shallow marine cloud properties. Although the link between ocean productivity and $\mathrm{CCN}$ has been shown to be mediated through a range of intermediate species that are subject to considerable variability over different timescales, most studies suggest a strong correlation between remotely sensed surface Chlorophyll $a([\mathrm{Chl}-a])$ and liquid cloud effective radii $\left(r_{e}\right)[32,39-47]$. An exception is the study of Miller and Yuter [48] (hereon MY08), who did not find a correlation between [Chl- $a$ ] and $r_{e}$ and questioned the conclusions of previous studies. This diversity of conclusions reflects the complexity of studying marine biogenic aerosolcloud interactions. Owing to the dynamic nature of oceanic aerosol sources, large signal-to-noise ratio and coarse spatial resolution of remote sensing products, unraveling the links between ocean ecosystems, aerosols, and clouds requires a carefully-thought statistical analysis method.

This study has two goals. First, to identify sources of uncertainty in studying the correlation between [Chl- $a$ ] and $r_{e}$ and provide guidelines on the optimum selection of statistical methods, time periods and oceanic regions. These guidelines are then applied to study the correlation between [Chl- $a$ ] and $r_{e}$ over different regions and time periods (including those in the MY08 study). Second, we present a novel approach for separating sea salt and nonsea salt (nss) components of aerosol optical depth (AOD) over the ocean and its application to determining the effect of ocean primary productivity on marine $\mathrm{CCN}$.

\section{Methods}

The remotely sensed data used in this study include the Seaviewing Wide Field-of-view Sensor (SeaWiFS) 8 day averaged $\sim 9 \mathrm{~km}$ resolution [Chl- $a$ ] data, Quick Scatterometer (QuikSCAT) derived daily ocean surface wind speed $\left(U_{10}\right)$ at $0.25^{\circ} \times 0.25^{\circ}$ spatial resolution, and Moderate Resolution Imaging Spectroradiometer (MODIS/Terra) Collection 5 (C5) Level-3 global quality assured-(QA-) weighted daily averaged liquid cloud (i.e., cloud cover, thermodynamic phase, liquid water path, and optical depth) and AOD products gridded at $1^{\circ} \times 1^{\circ}$ spatial resolution. To be consistent
TABLE 1: Regression statistics for ss-AOD versus surface wind speed.

\begin{tabular}{|c|c|c|}
\hline Correlation & $r^{2}$ & Source \\
\hline ss- $\mathrm{AOD}_{500}=0.0068 * U+0.056$ & 0.14 & {$[57]$} \\
\hline ss-AOD ${ }_{1020}=0.0093^{*} U+0.018$ & 0.27 & {$[57]$} \\
\hline ss- $\mathrm{AOD}_{500}=0.00055^{*} U^{2.195}+0.06$ & $0.97^{*}$ & {$[58]$} \\
\hline ss-AOD ${ }_{555}=0.00016^{*} U^{2.3}+0.036$ & 0.36 & [59] \\
\hline
\end{tabular}

between different satellite sensors all the data for the years 2002-2008 were area-averaged and regridded to $1^{\circ} \times 1^{\circ}$ resolution. The MODIS aerosol algorithm was designed to minimize cloud contamination by using a sensitive cloud detection algorithm $[49,50]$. In addition, aerosol data with AOD $>0.8$ were removed from the analysis to avoid misclassification of clouds and aerosols [51]. Nevertheless it has been shown that the MODIS AOD retrievals may still contain residual artifacts introduced by clouds $[52,53]$, by $3 \mathrm{D}$ effects near clouds $[54,55]$ and by physical changes to the "aerosol" in the vicinity of clouds [56].

To derive the relationship between sea salt AOD (ssAOD) and $U_{10}$ we have chosen the linear function of Smirnov et al. [57] and the power law of Mulcahy et al. [58] and Glantz et al. [59]. Marine background AOD regression statistics for the relationship of Smirnov et al. [57] was derived using 10 years of the Aerosol Robotic Network (AERONET) data collected at Midway Islands (Sand Island) in the northern Pacific Ocean at $\left(28.2^{\circ} \mathrm{N}\right.$ and $\left.177.4^{\circ} \mathrm{W}\right)$. Visual inspection of the global [Chl- $a$ ] distribution shows that Sand Island is surrounded by ocean waters with very low productivity (see Figure 1 in Supplementary Material available online at doi:10.1155/2010/239808). It is therefore expected that marine aerosols at Sand Island will not be influenced considerably by primary productivity. In addition, anthropogenic contribution to AOD in this remote oceanic region is also very low [60], suggesting that AODwind relationship derived at Midway Islands can be used to estimate the ss-AOD. Measurements of Mulcahy et al. [58] were carried out from January 2002 to December 2004 at the Mace Head global atmosphere watch (GAW) research station on the west coast of Ireland $\left(53.3^{\circ} \mathrm{N}, 9.9^{\circ} \mathrm{W}\right)$. The study was strictly limited to winter periods (November-March) and clean marine air masses, where sea salt aerosol is expected to dominate AOD. Sea salt dominated all aerosol size ranges during wintertime with little influence of biogenically produced inorganic and organic matter to the marine aerosol mass $[22,24]$. The relationship between ss-AOD and the $U_{10}$ offered by Glantz et al. [59] was estimated by combining SeaWiFS AOD with surface wind speed obtained from the European Centre for Medium-Range Weather Forecasts (ECMWF). The regression statistics from all three studies are summarized in Table 1.

The contribution of ss-AOD to total remotely sensed AOD over the ocean are examined using different satellites with different equatorial crossing times. SeaWiFS is in 
descending sun-synchronous near-polar circular orbit with $\sim 12: 20$ LT equator crossing time, MODIS/Terra is in a descending node with $\sim 10: 30$ LT equator crossing time, the $U_{10}$ was derived as average of both ascending $(\sim 6: 00 \mathrm{LT})$ and descending $(\sim 18: 00 \mathrm{LT})$ paths of QuikSCAT. Such approach is not expected to introduce any significant errors in our analysis as the characteristic time scale of [Chl- $a$ ] variability is about a week [61] and the correlation time between the surface winds and the marine aerosol (away from the continents) is sufficient for MODIS and QuikSCAT retrievals to be connected [62].

\section{The Statistical Analysis}

An approach to evaluate the spatial correlation between phytoplankton abundance ([Chl- $a]$ ) and marine cloud properties (e.g., $r_{e}$ ) by contrasting cloud properties over the "blooms" (defined as a subset of grid boxes with average [Chl- $a$ ] above some threshold, for example, $[$ Chl- $a]>1$ $\mathrm{mg} \mathrm{m}^{-3}$ used in MY08) against "nonbloom" grid boxes can lead to erroneous conclusions as shown below. The correlation coefficient, $R_{[\mathrm{Chl}-a], r_{e}}$, between [Chl- $\left.a\right]$ and $r_{e}$ can be written as

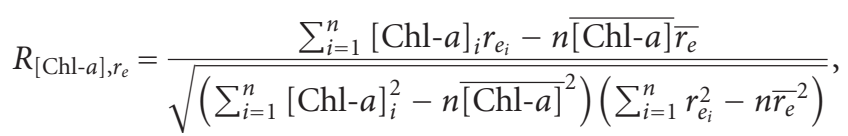

where $\overline{[\mathrm{Chl}-a]}$ and $\overline{r_{e}}$ are sample means, [Chl- $\left.a\right]_{i}$ and $r_{e i}$ are the sample dataset, and $n$ is the sample size. From (1) it follows that conditional sampling of the data (set by the arbitrary bloom threshold [Chl-a]) can alter the magnitude of $R_{[\mathrm{Chl}-a], r_{e}}$. An example that illustrates this is presented in Table 2, which shows that positive, negative or no correlation between [Chl- $a$ ] and $r_{e}$ can be obtained by changing the [Chl-a] threshold values for the dataset. Table 2 also reveals that such "bloom area" criteria can reduce sample size to $<5 \%$ of available data, making the results statistically unreliable.

The above example illustrates that in correlation analysis between [Chl- $a$ ] and $r_{e}$ bloom and nonbloom regions should not be considered separately; instead all data-points should be included. Moreover, depending on ambient conditions, maximum [Chl- $a]$ in a bloom can vary considerably (e.g., from 0.6 to $23,[63]$ ). This relativity of the bloom strength makes it difficult to define a universal threshold for [Chl-a] value and can lead to biased conclusions. Overall, the usage of a [Chl-a] threshold should be avoided in statistical analyses.

\section{Selection of Spatial Resolution for Remotely Sensed Data}

When examining the relationship between ocean ecosystem and overlying clouds it is typical to use specific oceanic regions and time periods. Although the effect of ocean productivity on marine clouds does not scale linearly with [Chl-a], it is desirable to examine the possible relationship between [Chl- $a$ ] and $r_{e}$ for periods with extensive blooms and the regions where cloud properties are not dominated by other types of aerosol interactions (e.g., strong dust or biomass burning plumes). The areas of elevated ocean primary productivity downwind of East Asia and West African Coast may not be ideal for detecting biogenic signals in $r_{e}$, as these regions are known to be strongly impacted by anthropogenic and mineral dust aerosol $[64,65]$. This, in conjunction with the threshold-based statistical approach, may explain the lack of correlation between [Chl-a] and $r_{e}$ reported by MY08. Indeed, the area-averaged monthly mean MODIS retrieved AOD values at $550 \mathrm{~nm}\left(\mathrm{AOD}_{\mathrm{M}}^{550}\right)$ for the regions used in MY08 analysis were larger than 0.3 and the area-averaged daily $\mathrm{AOD}_{\mathrm{M}}^{550}$ values often reached 0.5 (not shown). Under such high (non-biogenic) aerosol loadings it will be difficult, if not impossible, to identify the biogenic effects on marine cloud properties.

Owing to its unique spatial location and circumpolar nature, the Southern Ocean (SO) remains an ideal place for examining the effects of marine productivity on liquid clouds using remotely sensed data. Primary productivity in the SO is peaking during the austral summer and gradually declining with a minimum in winter. Waters in the SO can support massive phytoplankton blooms [32, 66, 67], with [Chl-a] more than an order of magnitude higher than the background levels $[68,69]$. The SO is characterized with minimal influence by mineral dust and also remains to be one of the most pristine regions of the globe with little impact from anthropogenic pollution. The surface [Chla] in this area can be used as a reliable proxy for the primary production $[66,70]$. Strong and persistent westerlies with weak latitudinal component [71] make it possible to examine cloud properties upwind and downwind of the bloom. Although it is practically impossible to fully separate the effects of aerosols and meteorology on cloud microphysical properties, studies have shown $[32,44]$ that over the Southern Ocean CCN concentration does not correlate well with surface wind speed, precipitation, or sea surface temperature (SST). The periodic nature of the blooms (with distinct intraseasonal and interannual variability often out of phase from other periodic signals that may affect cloud properties) is ideal for exploring the temporal relationship between ocean productivity and regional clouds. When examining the correlation between marine productivity and cloud properties with remote sensing, it is important to properly select the spatial resolution for the data averaging. For example, the effect of secondary aerosols, which are the outcome of gas-to-particle processes, should generally appear not over the bloom, but farther downwind. Modeling results of Woodhouse et al. [72] show that DMS oxidation could influence condensational growth of existing particles not over the bloom, but $\sim 100 \mathrm{~km}$ downwind, although the effect on CCN number may occur several thousand kilometers downwind of the bloom. The effect of marine primary organic aerosols generated at the sea surface through wind driven processes should be more centered in near the bloom region. Based on the lifetime of (1-2 hrs) for some of the phytoplankton produced VOCs over the SO [73] and the mean wind speed of $\sim 40 \mathrm{~km} / \mathrm{hr}$ [74], the effect of marine-SOA on clouds should appear $\sim 100 \mathrm{~km}$ downwind 
TABLE 2: Correlations of [Chl-a] and $r_{e}$ for the events chosen in MY08, using different threshold values of [Chl-a] that define the phytoplankton "bloom."

\begin{tabular}{|c|c|c|c|c|c|}
\hline Location (Date Range) & {$[$ Chl- $a]$ threshold $\mathrm{mg} \mathrm{m}^{-3}$} & $R_{[\mathrm{Chl}-a], r_{e}}^{(\mathrm{a})}$ & $R_{\lim }{ }^{(\mathrm{b})}$ & Sample size & $\begin{array}{c}\text { Percent of data points } \\
\text { satisfying the [Chl-a] } \\
\text { threshold }(\%) \\
\end{array}$ \\
\hline \multirow{7}{*}{$\begin{array}{l}\text { Southern Atlantic }-48^{\circ} \mathrm{S} \text { to } 56^{\circ} \mathrm{S}, 55^{\circ} \mathrm{W} \\
\left.\text { to } 21^{\circ} \mathrm{W} \text { ( } 11 \text { Dec. } 2001-8 \text { Jan. } 2002\right)\end{array}$} & No cutoff & -0.25 & $\begin{array}{l}-0.32 \\
-0.17\end{array}$ & 645 & 97 \\
\hline & $>0.5$ & -0.38 & $\begin{array}{l}-0.49 \\
-0.26\end{array}$ & 211 & 32 \\
\hline & $>1.0$ & $-0.55 \quad(-0.67)$ & $\begin{array}{l}-0.71 \\
-0.36\end{array}$ & 64 & 10 \\
\hline & $>1.5$ & -0.29 & $\begin{array}{c}-0.59 \\
0.08\end{array}$ & 31 & 5 \\
\hline & $>2.0$ & -0.17 & $\begin{array}{c}-0.58 \\
0.31\end{array}$ & 20 & 3 \\
\hline & $>2.5$ & +0.08 & $\begin{array}{c}-0.47 \\
0.59\end{array}$ & 15 & 2.3 \\
\hline & $<1.0$ & $-0.1 \quad(-0.02)$ & $\begin{array}{l}-0.18 \\
-0.02 \\
\end{array}$ & 582 & 88 \\
\hline \multirow{3}{*}{$\begin{array}{l}\text { Sea of Okhotsk- } 57^{\circ} \mathrm{N} \text { to } 52^{\circ} \mathrm{N} \text { and } \\
146^{\circ} \mathrm{E} \text { to } 152^{\circ} \mathrm{E}(26 \text { June } 2003-27 \text { July } \\
2003 \text { ) }\end{array}$} & No cutoff & 0.14 & $\begin{array}{c}-0.18 \\
0.42\end{array}$ & 43 & 100 \\
\hline & $>1.0$ & $0.13(-0.02)$ & $\begin{array}{c}-0.35 \\
0.55\end{array}$ & 20 & 48 \\
\hline & $<1.0$ & $-0.17 \quad(-0.13)$ & $\begin{array}{l}-0.55 \\
0.26\end{array}$ & 24 & 55 \\
\hline \multirow{3}{*}{$\begin{array}{l}\text { Northwest Atlantic }-42^{\circ} \mathrm{N} \text { to } 60^{\circ} \mathrm{N} \text { and } \\
\left.55^{\circ} \mathrm{W} \text { to } 21^{\circ} \mathrm{W}\right)(5 \mathrm{Aug} .2003-4 \text { Sep. } \\
\text { 2004) }\end{array}$} & No cutoff & -0.51 & $\begin{array}{l}-0.57 \\
-0.46\end{array}$ & 658 & 99 \\
\hline & $>1.0$ & $-0.21(-0.09)$ & $\begin{array}{c}-0.52 \\
0.16\end{array}$ & 32 & 5 \\
\hline & $<1.0$ & $-0.56(-0.18)$ & $\begin{array}{l}-0.61 \\
-0.5\end{array}$ & 627 & 94 \\
\hline \multirow{3}{*}{$\begin{array}{l}\text { West African Coast }-4^{\circ} \mathrm{N} \text { to } 14^{\circ} \mathrm{S} \text { and } \\
20^{\circ} \mathrm{W} \text { to } 14^{\circ} \mathrm{E}(1 \text { Jan. } 2002-1 \text { Feb. } 2002)\end{array}$} & No cutoff & -0.03 & $\begin{array}{c}-0.12 \\
0.06\end{array}$ & 449 & 68 \\
\hline & $>1.0$ & $-0.09(0.02)$ & $\begin{array}{c}-0.41 \\
0.24\end{array}$ & 38 & 6 \\
\hline & $<1.0$ & $0.13(0.13)$ & $\begin{array}{l}0.04 \\
0.23\end{array}$ & 412 & 62 \\
\hline \multirow{3}{*}{$\begin{array}{l}\text { Bering Sea-52 } 2^{\circ} \mathrm{N} \text { to } 70^{\circ} \mathrm{N} \text { and } 176^{\circ} \mathrm{E} \text { to } \\
150^{\circ} \mathrm{W}(6 \mathrm{Apr} .2004-7 \text { May } 2004)\end{array}$} & No cutoff & -0.45 & $\begin{array}{l}-0.53 \\
-0.35\end{array}$ & 326 & 49 \\
\hline & $>1.0$ & $-0.42(-0.13)$ & $\begin{array}{l}-0.55 \\
-0.27\end{array}$ & 139 & 21 \\
\hline & $<1.0$ & $0.04(-0.1)$ & $\begin{array}{c}-0.11 \\
0.18\end{array}$ & 188 & 28 \\
\hline
\end{tabular}

$\overline{{ }^{(a)} \text { Values in parenthesis are from MY08; highlighted values are the episodes when discrepancies between our and MY08 results were outside the } 95 \% \text { confidence }}$ intervals.

(b) The 95\% confidence limits (the upper and lower bounds of a 95\% confidence interval). 
from the bloom. This distance may vary in different parts of the oceans based on chemical loss rates of VOCs and potential aid of organic vapors (from the oxidation products of marine sources of VOCs) to the nucleation events and growth of ultrafine particles $[75,76]$. Therefore, when examining the relationship between ocean productivity and physical properties of shallow marine clouds over the SO using remotely sensed data, best correlation is likely to be achieved at $2^{\circ} \times 2^{\circ}$ averaged grid boxes (roughly $100-150 \mathrm{~km}$ $\times 220 \mathrm{~km}$ in the SO).

\section{Negative Correlation between [Chl- $a]$ and $r_{e}$}

Figures 1 and 2 show correlation between [Chl- $a$ ] and $r_{e}$ over the Northwest Atlantic and the Bering Sea regions for the same time periods and the datasets used in MY08 (see Table 2). Figure 1 demonstrates that during the bloom period, out of all variables examined, $r_{e}$ is primarily correlated with [Chl-a] with $R_{[\mathrm{Chl}-a], \mathrm{r}_{\mathrm{e}}} \sim-0.5$ (see Table 2). Figure 2 shows that over the low [Chl-a] regions of the Bering Sea, monthly averaged cloud effective radii is $\sim 15$ to $18 \mu \mathrm{m}$, with sharp decrease $(\sim 10 \mu \mathrm{m})$ in the vicinity of the bloom region. Considerable negative correlation $\left(R_{[\mathrm{Chl}-a], \mathrm{r}_{\mathrm{e}}} \sim-0.4\right)$ was also obtained for this episode with large discrepancies (highlighted values) between our results and the ones reported in MY08 (Table 2). Additional case studies over the Southern Indian Ocean and South Atlantic Ocean (Figure 3, Table 3) also show significant negative correlations between [Chl- $a$ ] and $r_{e} ; R_{[\mathrm{Chl}-a], r_{e}}$ values inside $(-0.45,-0.38$ and -0.22$)$ and outside $(-0.09,-0.29$ and 0.07 ) the bloom regions of Figure 3 are significantly different, suggesting that marine biota could influence shallow marine cloud properties.

\section{Retrieved AOD not Associated with Sea Salt}

A major issue for quantifying the climatic effects of marine biogenic aerosols with the use of satellite data is the dominance of aerosol mass loading over the oceans by sea salt and aerosols of terrestrial origin. Detection of ocean biologically generated aerosols is further complicated due to their small size and low scattering efficiency. Here we employ a novel approach by examining the differences between MODIS-AOD and ss-AOD (AOD diff) at different wavelengths. If sea salt aerosols were the only ones affecting observed top of the atmosphere (TOA) reflectances over the oceans, one expects to see very low and uniform values for $A O D_{\text {diff. }}$ On the other hand, if aerosols other than sea salt can be important, $\mathrm{AOD}_{\text {diff }}$ is expected to highlight the regions where nss-aerosols contribute to the observed reflectances. Figures 4(a) and 4(b) show large regions of Atlantic Ocean (east of Africa), Pacific Ocean (downwind from east Asia), Indian Ocean (west of Singapore and Indonesia), Arabian sea and Bay of Bengal, with sizable positive values for the $\mathrm{AOD}_{\text {diff }}$ at $550 \mathrm{~nm}\left(\mathrm{AOD}_{\text {diff }}^{550}\right)$. These figures show that the regions highlighted by warm colors on Figure 4(b) (positive difference between MODIS-AOD and ss-AOD) are typically associated with mineral dust and/or anthropogenic aerosol

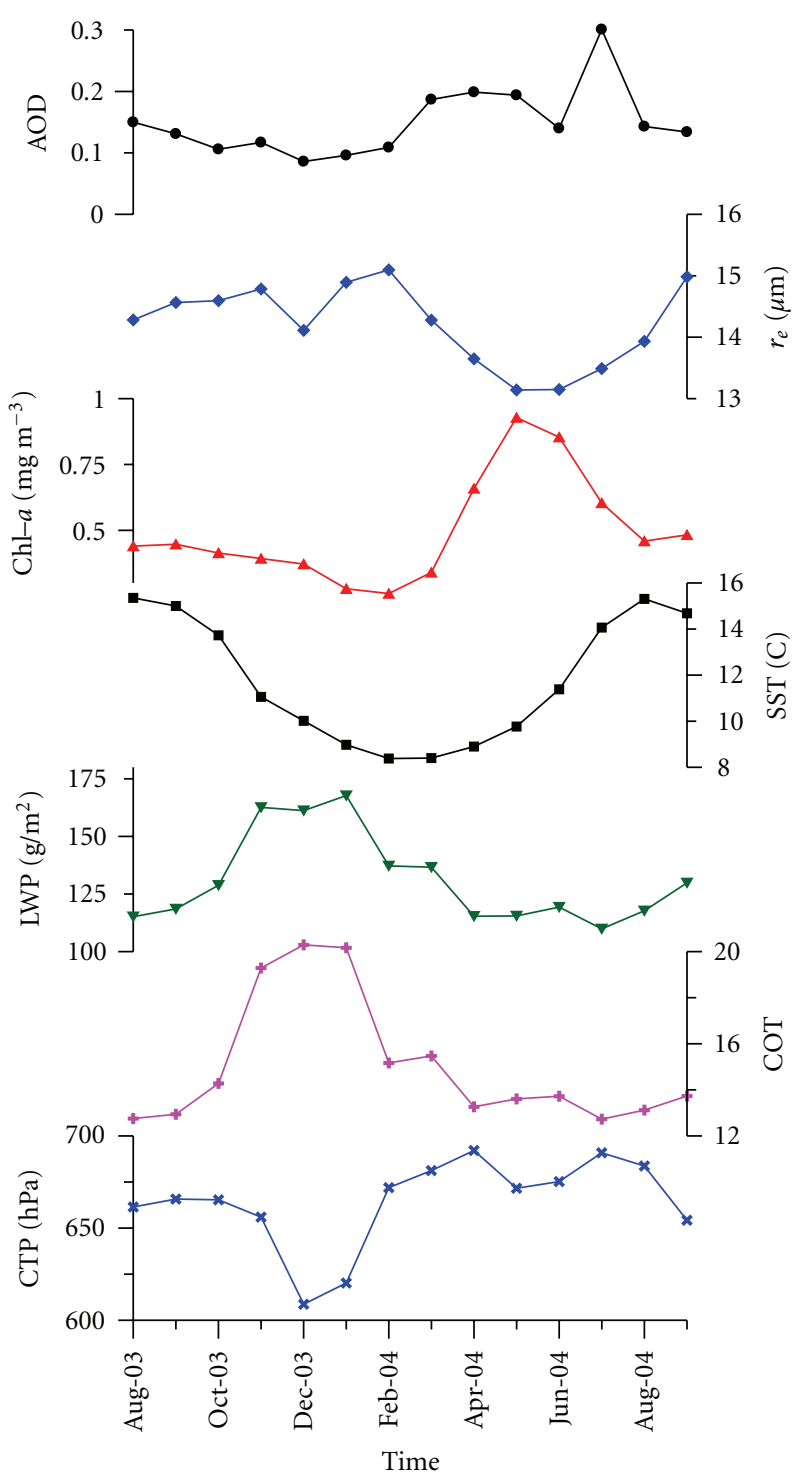

Figure 1: Time series of the area-averaged MODIS Aerosol optical depth (AOD), liquid cloud effective radii $\left(r_{e}\right)$, sea surface temperature (SST), liquid water path (LWP), liquid cloud optical thickness (COT), liquid cloud top pressure (CTP) and SeaWiFS [Chl- $a$ ] in Northwest Atlantic $\left(42^{\circ} \mathrm{N}\right.$ to $60^{\circ} \mathrm{N}$ and $55^{\circ} \mathrm{W}$ to $\left.21^{\circ} \mathrm{W}\right)$.

(i.e., biomass burning, industrial emissions). Interestingly, Figure 4(b) also shows positive values for $\mathrm{AOD}_{\text {diff }}^{550}$ over the SO, the region characterized by minor contribution from both anthropogenic aerosols and mineral dust. Variations in size distribution of various aerosol types have been shown to strongly influence the radiative properties of the aerosols such as the scattering phase function, single scattering albedo and spectral variation of AOD [77]. AOD retrieved from sensing at shorter wavelengths are more sensitive to accumulation mode aerosol, while the larger wavelengths are more sensitive to coarse particles. Therefore, the $A O D_{\text {diff }}$ can be used to infer the relative importance of aerosol generation processes. Figure 4(c) shows the difference between MODIS-AOD and ss-AOD at wavelength 
TABLE 3: Correlations of [Chl- $a$ ] and $r_{e}$ for different events of Figure 3.

\begin{tabular}{|c|c|c|c|}
\hline & Location (date range) & & $\begin{array}{l}\text { Correlation coefficient } \\
\text { between [Chl- } a \text { ] and } r_{e}\end{array}$ \\
\hline \multirow{2}{*}{$\begin{array}{l}\text { Southern Indian (25 November 2006-31 } \\
\text { December 2006) }\end{array}$} & $46^{\circ} \mathrm{S}$ to $52^{\circ} \mathrm{S}, 65^{\circ} \mathrm{E}$ to $105^{\circ} \mathrm{E}$ & Inside the boom & -0.45 \\
\hline & $\begin{array}{l}42^{\circ} \mathrm{S} \text { to } 46^{\circ} \mathrm{S}, 65^{\circ} \mathrm{E} \text { to } 105^{\circ} \mathrm{E} \\
52^{\circ} \mathrm{S} \text { to } 60^{\circ} \mathrm{S}, 65^{\circ} \mathrm{E} \text { to } 105^{\circ} \mathrm{E}\end{array}$ & Outside the bloom & -0.09 \\
\hline \multirow{2}{*}{$\begin{array}{l}\text { Southern Atlantic ( } 10 \text { December 2004-08 } \\
\text { January 2005) }\end{array}$} & $50^{\circ} \mathrm{S}$ to $54^{\circ} \mathrm{S}, 55^{\circ} \mathrm{W}$ to $21^{\circ} \mathrm{W}$ & Inside the boom & -0.38 \\
\hline & $\begin{array}{l}42^{\circ} \mathrm{S} \text { to } 50^{\circ} \mathrm{S}, 55^{\circ} \mathrm{W} \text { to } 21^{\circ} \mathrm{W} \\
54^{\circ} \mathrm{S} \text { to } 60^{\circ} \mathrm{S}, 55^{\circ} \mathrm{W} \text { to } 21^{\circ} \mathrm{W}\end{array}$ & Outside the bloom & -0.29 \\
\hline \multirow{2}{*}{$\begin{array}{l}\text { Southern Atlantic ( } 11 \text { December 2002-08 } \\
\text { January 2003) }\end{array}$} & $50^{\circ} \mathrm{S}$ to $56^{\circ} \mathrm{S}, 55^{\circ} \mathrm{W}$ to $21^{\circ} \mathrm{W}$ & Inside the boom & -0.22 \\
\hline & $\begin{array}{l}42^{\circ} \mathrm{S} \text { to } 50^{\circ} \mathrm{S}, 55^{\circ} \mathrm{W} \text { to } 21^{\circ} \mathrm{W} \\
56^{\circ} \mathrm{S} \text { to } 60^{\circ} \mathrm{S}, 55^{\circ} \mathrm{W} \text { to } 21^{\circ} \mathrm{W}\end{array}$ & Outside the bloom & -0.07 \\
\hline
\end{tabular}

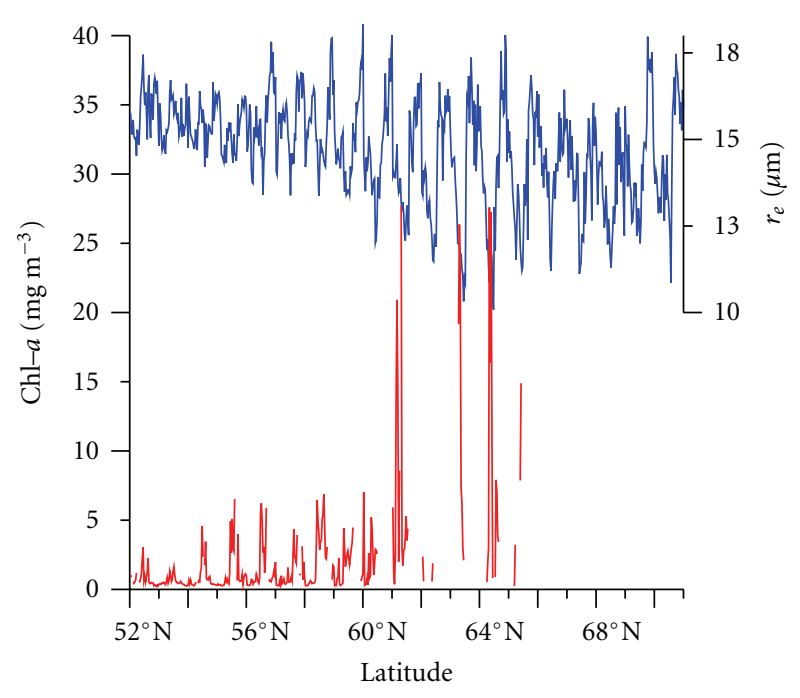

Figure 2: The $1^{\circ} \times 1^{\circ}$ square monthly averaged SeaWiFS-observed [Chl-a] (red) and MODIS cloud effective radii (blue) over the Bering Sea. Between every tick marker on the $x$-axis, there are 35 data points corresponding to the starting point of the next westto-east row in the longitudinal direction $\left(176^{\circ} \mathrm{E}\right.$ to $\left.150^{\circ} \mathrm{W}\right)$. The large portion of the [Chl- $a$ ] data is missing due to the inclusion of continental regions.

of $1020 \mathrm{~nm}\left(\mathrm{AOD}_{\mathrm{diff}}^{1020}\right)$. When compared against $\mathrm{AOD}_{\text {diff }}^{550}$ shown on Figure $4(\mathrm{~b}), \mathrm{AOD}_{\text {diff }}^{1020}$ is generally smaller, and effectively zero in pollution-dominated oceanic regions (e.g., downwind from eastern North America, east Asia and Indonesia). This is expected, as aerosol in these regions is dominated by submicron particles that scatter more effectively at shorter wavelengths. Comparison of Figures 4 (b) and 4(c) also reveals smaller $\mathrm{AOD}_{\text {diff }}^{1020}$ than $\mathrm{AOD}_{\text {diff }}^{550}$ over the SO, suggesting that an accumulation mode aerosol is ubiquitous over the SO. It should be noted that these AOD differences over the SO are statistically significant, as they represent long-term averages with values much larger than the uncertainties in MODIS retrievals over the oceans [78].

To elucidate the role of ocean biology in the observed $\mathrm{AOD}_{\text {diff }}^{550}$, we examined the time series of [Chl- $\left.a\right]$ and $\mathrm{AOD}_{\text {diff }}^{550}$ in seven SO regions (Figure 4(a)) characterized by massive phytoplankton blooms during the austral summer and one in the central South Pacific gyre known as "the Earth's largest oceanic desert" [79]. The AOD diff $^{550}$ were derived using three different ss-AOD parameterizations of Smirnov et al. [57], Mulcahy et al. [58] and Glantz et al. [59]. Figure 5 shows temporal correlations between $\mathrm{AOD}_{\text {diff }}^{550}$ and [Chl- $a$ ] for selected oceanic regions, which are statistically significant at the $95 \%$ confidence level (Table 4 ). Figure 5 shows that during the austral summer similar patterns are seen in the SO between ocean surface productivity and the abundance of accumulation mode aerosol not associated with sea salt (Figure 5 and Table 4). During the high wind season (austral winter), the $\mathrm{AOD}_{\text {diff }}^{550}$ turns negative (particularly using the Mulcahy et al. [58] regression), indicating potential overestimation of sea salt contribution to observed AOD. Unlike other stations, however, the $[\mathrm{Chl}-a]$ and AOD $\mathrm{Diff}_{\text {data from }}$ Station 8 (Figure 5(h); Table 4 ) show negative correlations, suggesting that the source of accumulation mode aerosol may differ between high and low productivity regions. Although aerosol measurements made over the high ocean productivity regions suggest using [Chl-a] as a proxy for the emissions of marine organic matter $[80,81]$, recent study by Russell et al. [82] indicates that dissolved organic carbon (DOC) and particulate organic carbon (POC) concentrations in the sea surface microlayer may provide the source of organic aerosols in the Arctic and north Atlantic regions, respectively. It is interesting to notice, that the surface waters near the Station 8 have some of the highest levels of DOC in the entire South Pacific Ocean [83], and therefore can explain the absence of correlation between [Chl-a] and AOD diff. All together, this evidence suggests a robust link between marine productivity and accumulation mode aerosol (i.e., CCN) over the oceans and in particular the SO.

To address potential bias in aerosol retrievals from "cloud contamination", we have removed all aerosol data with AOD $>0.8$ (Removal of all aerosol retrievals that may be influenced from clouds could leads to complete loss of aerosol-cloud interaction information [84]). This analysis, nevertheless, does include several imperfections. The satellite signal is a combination of radiation from the atmosphere as well as from the surface. MODIS observed reflectances 


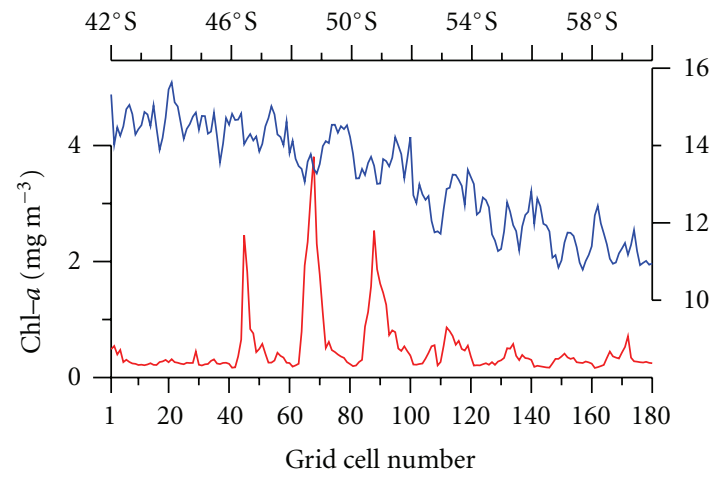

(a)

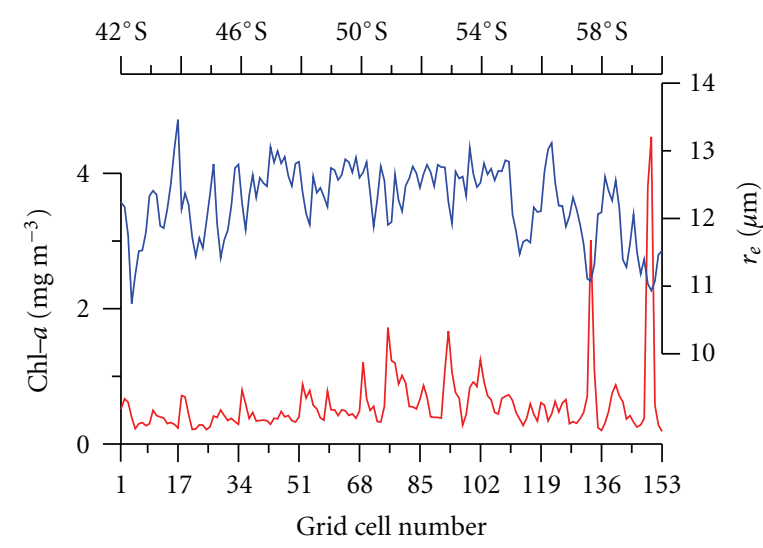

(c)

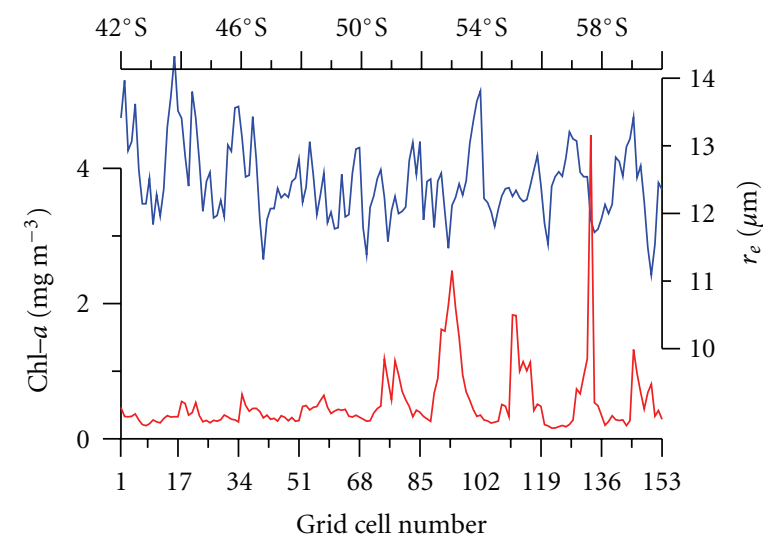

(e)

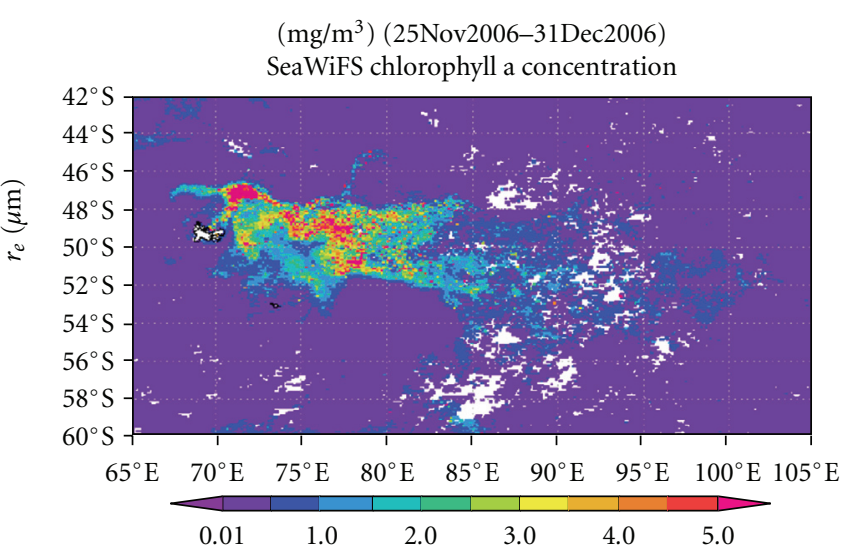

Generated by NASA's Giovanni (giovanni.qsfc.nasa.gav)

(b)

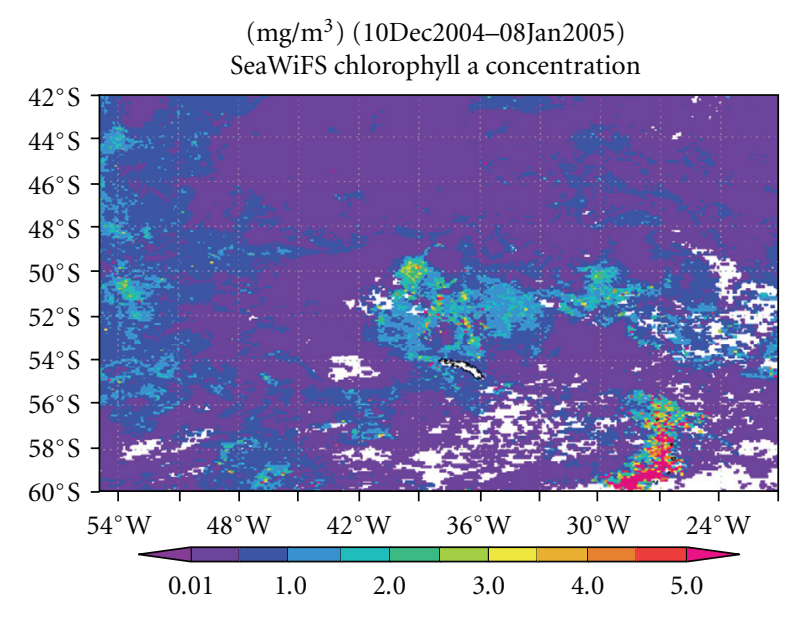

Generated by NASA's Giovanni (giovanni.qsfc.nasa.gav)

(d)

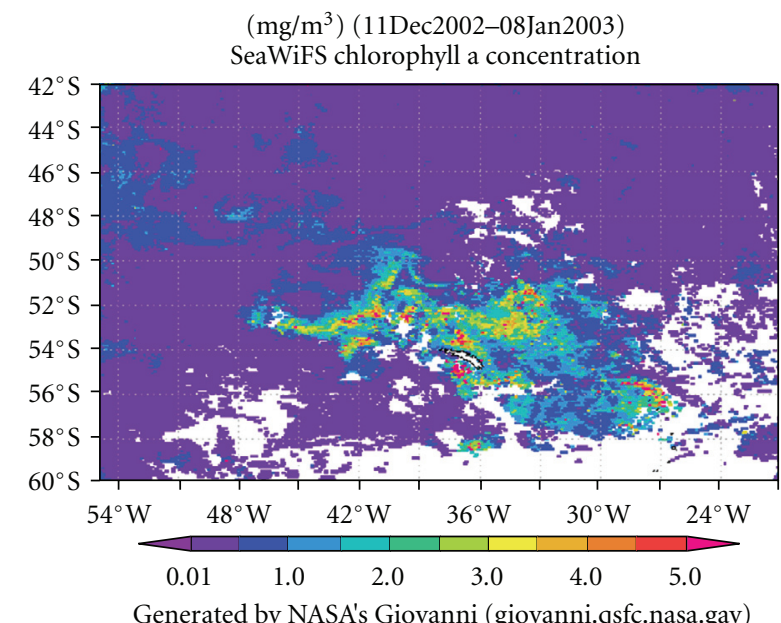

(f)

Figure 3: The $2^{\circ} \times 2^{\circ}$ square monthly averaged [Chl -a] and $r_{e}$ data for Southern Indian Ocean for (a), (b) 25 November 2006-31 November 2006; Southern Atlantic Ocean for (c), (d) 10 December 2004-08 January 2005; and Southern Atlantic Ocean for (e),(f) 11 December 200208 January 2003 . The white color over the ocean denotes the missing data due to clouds. The Kerguelen Island $\left(49.25^{\circ} \mathrm{S}-69.58^{\circ} \mathrm{E}\right)$ and the South Georgia Island $\left(54.25^{\circ} \mathrm{S}, 36.75^{\circ} \mathrm{W}\right)$ are shown by black contours. The method is adopted from Meskhidze and Nenes [32]. The images and data used in this figure were acquired using the GES-DISC Interactive Online Visualization ANd aNalysis Infrastructure (Giovanni) as part of the NASA's Goddard Earth Sciences (GES) Data and Information Services Center (DISC). 


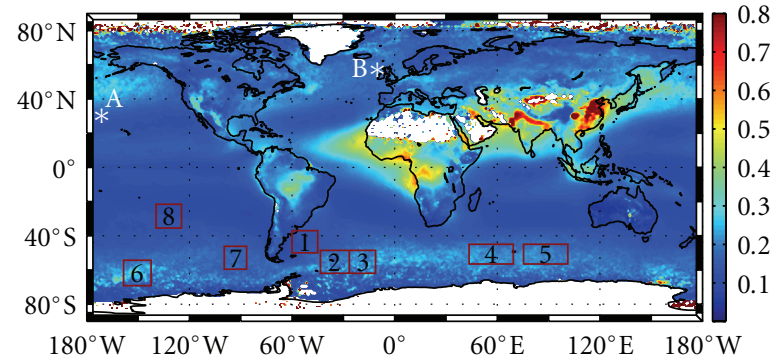

(a)

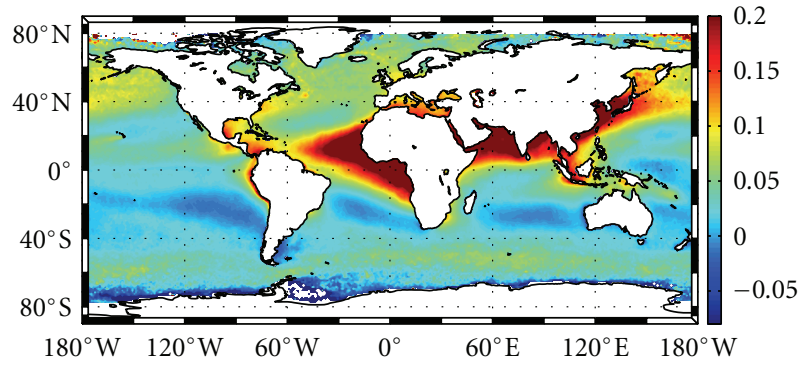

(b)

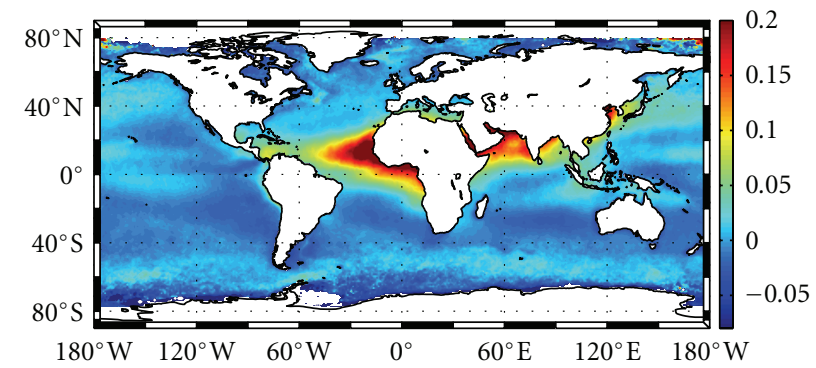

(c)

FIGURE 4: Seven-year (2002-2008) averaged daily data for (a) MODIS AOD at $550 \mathrm{~nm}$ and the differences between MODIS AOD and parameterized ss-AOD at (b) $550 \mathrm{~nm}$ and (c) $1020 \mathrm{~nm}$. The ss-AOD is calculated using Smirnov et al. [57] regression. Red boxes on Figure 4(a) indicate seven regions where time series analyses are carried out. Position of each boxes (latitude and longitude) are given in Table 4. Letters A and B denote locations of previous study areas of Smirnov et al. [57] at Midway Islands $\left(28.2^{\circ} \mathrm{N}\right.$ and $\left.177.4^{\circ} \mathrm{W}\right)$ and Mulchay et al. [58] at the Mace Head station $\left(53.3^{\circ} \mathrm{N}, 9.9^{\circ} \mathrm{W}\right)$, respectively. The study region of Glantz et al. [59] encompassed large areas of the North Pacific Ocean, roughly from $180^{\circ} \mathrm{W}$ to $160^{\circ} \mathrm{W}$ and $15^{\circ} \mathrm{N}$ to $45^{\circ} \mathrm{N}$.

TABLE 4: Correlations of [Chl-a] and $\mathrm{AOD}_{\text {diff }}$ for time series of Figure $5^{(1)}$.

\begin{tabular}{|c|c|c|c|c|}
\hline Location (Date Range) & {$[\mathrm{Chl}-a]$ and $\mathrm{AOD}_{\text {diff }}^{550^{(2)}}$} & {$[\mathrm{Chl}-a]$ and $\mathrm{AOD}_{\text {diff }}^{1020(3)}$} & {$[\mathrm{Chl}-a]$ and $\mathrm{AOD}_{\mathrm{diff}}^{550^{(4)}}$} & {$[\mathrm{Chl}-a]$ and $\mathrm{AOD}_{\text {diff }}^{550^{(5)}}$} \\
\hline Southern Atlantic & $0.60(0.52)$ & $0.41(0.30)$ & $0.60(0.52)$ & $0.59(0.50)$ \\
\hline Box \#1 $\left(39^{\circ} \mathrm{S}\right.$ to $47^{\circ} \mathrm{S}, 57^{\circ} \mathrm{W}$ to $\left.47^{\circ} \mathrm{W}\right)$ & $(0.66)$ & $(0.50)$ & $(0.67)$ & $(0.65)$ \\
\hline Southern Atlantic & $0.57(0.48)$ & $0.31(0.18)$ & $0.59(0.48)$ & $0.58(0.45)$ \\
\hline Box \#2 $\left(48^{\circ} \mathrm{S}\right.$ to $58^{\circ} \mathrm{S}, 43^{\circ} \mathrm{W}$ to $\left.31^{\circ} \mathrm{W}\right)$ & $(0.65)$ & $(0.41)$ & $(0.68)$ & $(0.68)$ \\
\hline Southern Atlantic & $0.54(0.44)$ & $0.30(0.15)$ & $0.56(0.44)$ & $0.35(0.23)$ \\
\hline Box \#3 $\left(48^{\circ} \mathrm{S}\right.$ to $58^{\circ} \mathrm{S}, 31^{\circ} \mathrm{W}$ to $\left.20^{\circ} \mathrm{W}\right)$ & $(0.61)$ & $(0.44)$ & $(0.66)$ & $(0.47)$ \\
\hline Southern Indian & $0.65(0.55)$ & $0.41(0.30)$ & $0.65(0.55)$ & $0.66(0.52)$ \\
\hline Box \#4 $\left(48^{\circ} \mathrm{S}\right.$ to $55^{\circ} \mathrm{S}, 44^{\circ} \mathrm{E}$ to $\left.64^{\circ} \mathrm{E}\right)$ & $(0.70)$ & $(0.51)$ & $(0.71)$ & $(0.72)$ \\
\hline Southern Indian & $0.40(0.28)$ & $0.18(0.07)$ & $0.49(0.38)$ & $0.43(0.32)$ \\
\hline Box \#5 $\left(47^{\circ} \mathrm{S}\right.$ to $55^{\circ} \mathrm{S}, 71^{\circ} \mathrm{E}$ to $\left.91^{\circ} \mathrm{E}\right)$ & $(0.49)$ & $(0.33)$ & $(0.54)$ & $(0.54)$ \\
\hline Southern Pacific & $0.35(0.21)$ & $0.03(-0.13)$ & $0.42(0.29)$ & $0.37(0.23)$ \\
\hline Box $\# 6\left(55^{\circ} \mathrm{S}\right.$ to $67^{\circ} \mathrm{S}, 159^{\circ} \mathrm{W}$ to $\left.145^{\circ} \mathrm{W}\right)$ & $(0.45)$ & $(0.14)$ & $(0.48)$ & $(0.48)$ \\
\hline Southern Pacific & $0.34(0.23)$ & $0.18(0.11)$ & $0.34(0.18)$ & $0.37(0.26)$ \\
\hline Box \#7 $\left(46^{\circ} \mathrm{S}\right.$ to $56^{\circ} \mathrm{S}, 100^{\circ} \mathrm{W}$ to $\left.90^{\circ} \mathrm{W}\right)$ & $(0.42)$ & $(0.32)$ & $(0.37)$ & $(0.47)$ \\
\hline Southern Pacific & $-0.25(-0.36)$ & $-0.15(-0.23)$ & $-0.38(-0.42)$ & $-0.21(-0.31)$ \\
\hline Box $\# 8\left(25^{\circ} \mathrm{S}\right.$ to $35^{\circ} \mathrm{S}, 135^{\circ} \mathrm{W}$ to $\left.125^{\circ} \mathrm{W}\right)$ & $(-0.15)$ & $(-0.05)$ & $(-0.23)$ & $(-0.12)$ \\
\hline
\end{tabular}

${ }^{(1)}$ Numbers in parenthesis show the upper and lower bounds of a $95 \%$ confidence interval.

(2) ss-AOD at $500 \mathrm{~nm}$ was calculated using Smirnov et al. [57] parameterization.

(3) $\mathrm{ss}-\mathrm{AOD}$ at $1020 \mathrm{~nm}$ was calculated using Smirnov et al. [57] parameterization.

${ }^{(4)} \mathrm{ss}-\mathrm{AOD}$ at $500 \mathrm{~nm}$ was calculated using Mulcahy et al. [58] parameterization.

${ }^{(5)}$ ss-AOD at $555 \mathrm{~nm}$ was calculated using Glantz et al. [59] parameterization. 


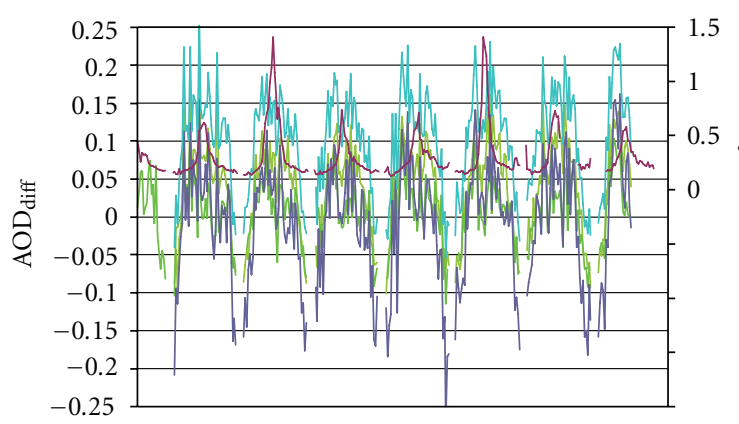

(a)

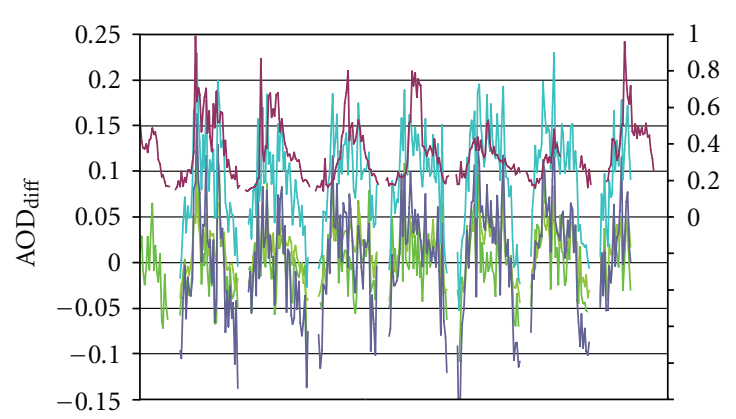

(c)

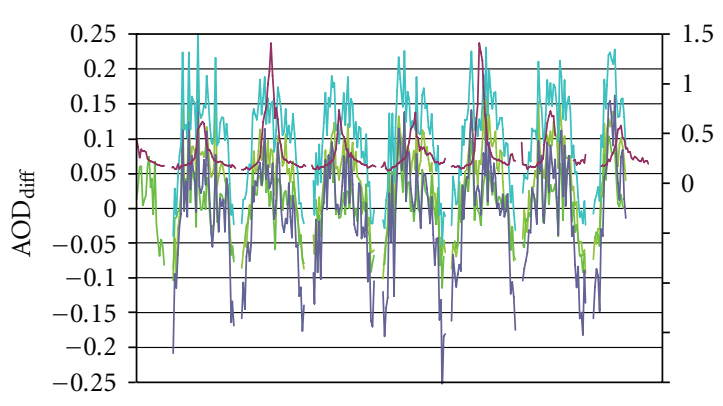

(e)

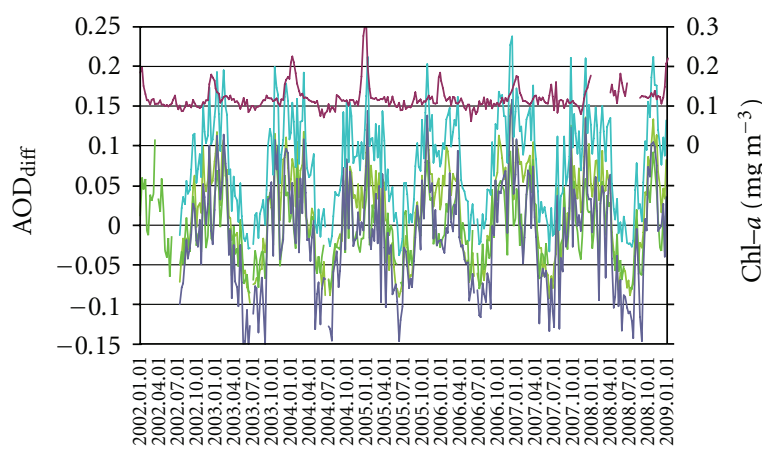

$\begin{aligned}- & \text { MODIS_AOD-Smirnov_AOD(500) } \\ - & \text { MODIS_AOD-Smirnov_AOD(1020) } \\ - & \text { MODIS_AOD-Smirnov_AOD(500) } \\ - & \text { MODIS_AOD-Smirnov_AOD(555) } \\ - & \text { [Chl-a] }\end{aligned}$

(g)

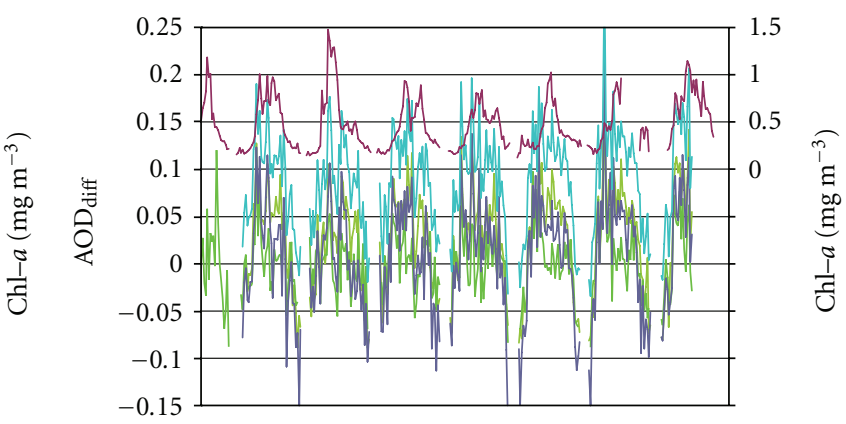

(b)

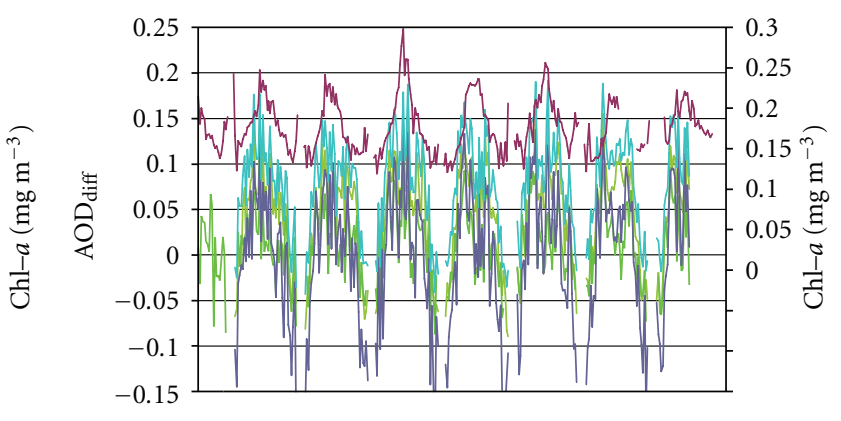

(d)

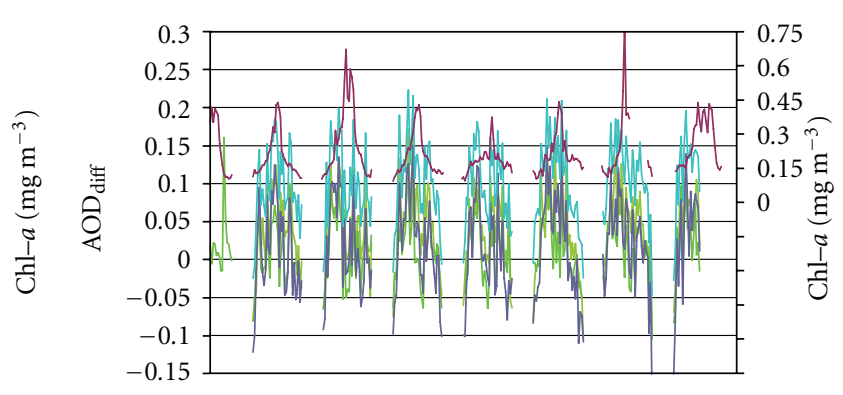

(f)

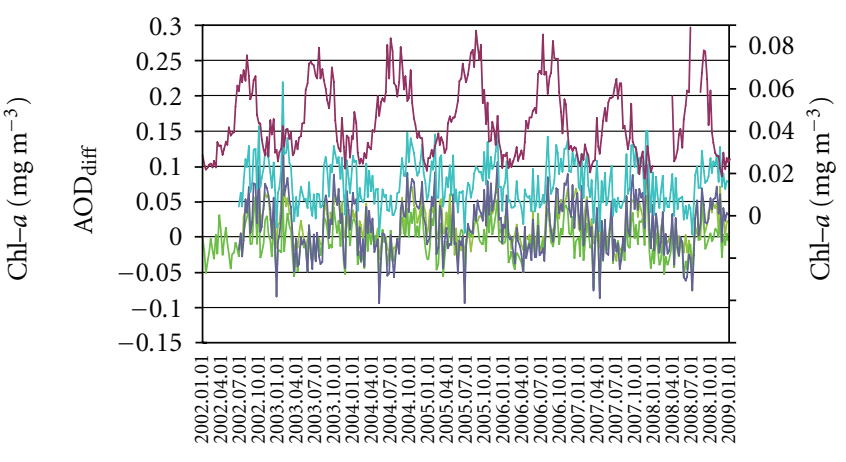

- MODIS_AOD-Smirnov_AOD(500)

- MODIS_AOD-Smirnov_AOD(1020)

- MODIS_AOD-Smirnov_AOD(500)

- MODIS_AOD-Smirnov_AOD(555)

- $[\mathrm{Chl}-a]$

FIgure 5: (a)-(h) Time series of the area-averaged $\mathrm{AOD}_{\text {diff }}$ (right axis) and [Chl-a] (left axis) for the boxes $1-8$ shown on Figure 4 . The daily differences in AOD values were averaged over 8 days. 
are then converted to AODs using nine tropospheric aerosol models [85]. The atmospheric contribution includes multiple scattering by gas and aerosol, as well as reflection of the atmosphere by the sea surface. The ocean surface calculation includes Sun glint reflection off the surface waves [86], reflection by whitecaps [87] and Lambertian reflectance from underwater scattering (sediments, chlorophyll, etc). For the current version of the lookup table, reflectances are calculated using a surface wind of $6.0 \mathrm{~m} / \mathrm{s}$. Zero water-leaving radiance is assumed at all six compared wavelengths, except for at $550 \mathrm{~nm}$, where a fixed reflectance of 0.005 is used [85]. Although this may lead to spurious correlations between $\mathrm{AOD}$ and [Chl- $a$ ] at high special resolution, it is not expected to have sizable influence when averaged over the large area as ones used in this study.

\section{Conclusion}

The use of remote sensing products is very valuable for studying marine biota-cloud links. Statistical analyses however must be carried out very carefully, using as much a priori knowledge as possible. We show that conditional sampling, and using periods and locations where aerosol from ocean biota are dwarfed by other sources can lead to biased conclusions. We propose guidelines that address these potential issues, and show that there is statistically significant negative correlation between warm cloud effective radii and surface ocean productivity in different parts of the ocean and different time periods. A novel approach, based on MODIS retrieved total aerosol optical depth and predicted sea salt aerosol optical depth $\left(\mathrm{AOD}_{\text {diff }}\right)$, is proposed to study the link between ocean biological productivity and submicron aerosols over the oceans. By employing different wavelength for estimating $\mathrm{AOD}_{\text {diff, }}$, it was proposed that the large summertime discrepancies between MODIS retrieved AODs and parameterized ss-AODs over the Southern Ocean are mainly related to accumulation model aerosols and cannot be explained by mere variations in column abundance of sea salt. Since the SO is characterized with minimal influence of anthropogenic pollution and mineral dust, summertime positive values in $\mathrm{AOD}_{\text {diff }}^{550}$ are most likely related to marine primary organic aerosols and secondary aerosols associated with biogenic trace gas emissions from the ocean.

Today it is widely accepted that the ocean ecosystem (particularly over the biologically active regions) can significantly influence CCN over the remote oceans. It has also been suggested that correct characterization of marine biogenic aerosols and factors that regulate their emissions could be essential for the accurate modeling of climate forcing assessments. However, satellite remote sensing alone cannot ascertain causal mechanism for the relationship between ocean ecosystem and properties of marine shallow clouds. Future studies through the combination of laboratory measurements, in situ data, satellite remote sensing and models are required to establish a comprehensive mechanism for this highly complex and interactive system of aerosol-ocean ecosystems-cloud interactions with multiple forcings and feedbacks.

\section{Acknowledgments}

This research was supported by the Office of Science (BER), US Department of Energy, Grant no. DE-FG02-08ER64508. The authors greatly appreciate the help in data processing by Brett Gantt.

\section{References}

[1] S. Twomey, "The influence of pollution on the shortwave albedo of clouds," Journal of Atmospheric Science, vol. 34, pp. 1149-1152, 1977.

[2] B. A. Albrecht, "Aerosols, cloud microphysics, and fractional cloudiness," Science, vol. 245, no. 4923, pp. 1227-1230, 1989.

[3] R. J. Charlson, S. E. Schwartz, J. M. Hales et al., "Climate forcing by anthropogenic aerosols," Science, vol. 255, no. 5043, pp. 423-430, 1992.

[4] IPCC, "Summary for policy makers," in Climate Change 2007: The Physical Science Basis. Contribution of Working Group I to the Fourth Assessment Report of the Intergovernmental Panel on Climate Change, S. Solomon, D. Qin, and M. Manning, Eds., Cambridge University Press, Cambridge, UK, 2007.

[5] S. A. Klein and D. L. Hartmann, "The seasonal cycle of low stratiform clouds," Journal of Climate, vol. 6, no. 8, pp. 15871606, 1993.

[6] S. Platnick and S. Twomey, "Determining the susceptibility of cloud albedo to changes in droplet concentration with the Advanced Very High Resolution Radiometer," Journal of Applied Meteorology, vol. 33, no. 5, pp. 334-347, 1994.

[7] D. A. Randell, J. A. Coakley Jr., C. W. Fairall, R. A. Kropfli, and D. H. Lenschow, "Outlook for research on subtropical marine stratiform clouds," Bulletin-American Meteorological Society, vol. 65, no. 12, pp. 1290-1301, 1984.

[8] B. Stevens, G. Vali, K. Comstock et al., "Pockets of open cells and drizzle in marine stratocumulus," Bulletin of the American Meteorological Society, vol. 86, no. 1, pp. 51-57, 2005.

[9] M. O. Andreae, "Aerosols before pollution," Science, vol. 315, no. 5808 , pp. 50-51, 2007.

[10] C. D. O'Dowd and G. De Leeuw, "Marine aerosol production: a review of the current knowledge," Philosophical Transactions of the Royal Society A, vol. 365, no. 1856, pp. 1753-1774, 2007.

[11] M. O. Andreae and D. Rosenfeld, "Aerosol-cloud-precipitation interactions. Part 1 . The nature and sources of cloud-active aerosols," Earth-Science Reviews, vol. 89, no. 1-2, pp. 13-41, 2008.

[12] C. D. O’Dowd, M. H. Smith, I. E. Consterdine, and J. A. Lowe, "Marine aerosol, sea-salt, and the marine sulphur cycle: a short review," Atmospheric Environment, vol. 31, no. 1, pp. 73-80, 1997.

[13] D. M. Murphy, J. R. Anderson, P. K. Quinn, et al., "Influence of sea-salt on aerosol radiative properties in the Southern Ocean marine boundary layer," Nature, vol. 392, no. 6671, pp. 62-65, 1998.

[14] P. K. Quinn, D. J. Coffman, V. N. Kapustin, T. S. Bates, and D. S. Covert, "Aerosol optical properties in the marine boundary layer during the first aerosol Characterization Experiment (ACE 1) and the underlying chemical and physical aerosol properties," Journal of Geophysical Research D, vol. 103, no. 13, pp. 16547-16563, 1998.

[15] C. Kleefeld, C. D. O’Dowd, S. O'Reilly et al., "Relative contribution of submicron and supermicron particles to aerosol light scattering in the marine boundary layer," Journal of Geophysical Research D, vol. 107, no. 19, article 8103, 2002. 
[16] T. S. Bates, P. K. Quinn, D. J. Coffman, J. E. Johnson, and A. M. Middlebrook, "Dominance of organic aerosols in the marine boundary layer over the Gulf of Maine during NEAQS 2002 and their role in aerosol light scattering," Journal of Geophysical Research D, vol. 110, no. 18, pp. 1-14, 2005.

[17] G. E. Shaw, "Bio-controlled thermostasis involving the sulfur cycle," Climatic Change, vol. 5, no. 3, pp. 297-303, 1983.

[18] R. J. Charlson, J. E. Lovelock, M. O. Andreae, and S. G. Warren, "Oceanic phytoplankton, atmospheric sulphur, cloud albedo and climate," Nature, vol. 326, no. 6114, pp. 655-661, 1987.

[19] T. Novakov, C. E. Corrigan, J. E. Penner, C. C. Chuang, O. Rosario, and O. L. Mayol Bracero, "Organic aerosols in the Caribbean trade winds: a natural source?" Journal of Geophysical Research D, vol. 102, no. 17, pp. 21307-21313, 1997.

[20] J.-P. Putaud, R. Van Dingenen, M. Mangoni et al., "Chemical mass closure and assessment of the origin of the submicron aerosol in the marine boundary layer and the free troposphere at Tenerife during ACE-2," Tellus, Series B, vol. 52, no. 2, pp. 141-168, 2000.

[21] F. Cavalli, M. C. Facchini, S. Decesari et al., "Advances in characterization of size-resolved organic matter in marine aerosol over the North Atlantic," Journal of Geophysical Research D, vol. 109, no. 24, pp. 1-14, 2004.

[22] Y. J. Yoon, D. Ceburnis, F. Cavalli et al., "Seasonal characteristics of the physicochemical properties of North Atlantic marine atmospheric aerosols," Journal of Geophysical Research D, vol. 112, no. 4, Article ID D04206, 2007.

[23] C. A. Pio, M. Legrand, T. Oliveira et al., "Climatology of aerosol composition (organic versus inorganic) at nonurban sites on a west-east transect across Europe," Journal of Geophysical Research D, vol. 112, no. 23, Article ID D23S02, 2007.

[24] C. D. O’Dowd, M. C. Facchini, F. Cavalli et al., "Biogenically driven organic contribution to marine aerosol," Nature, vol. 431, no. 7009, pp. 676-680, 2004.

[25] D. Ceburnis, C. D. O’Dowd, G. S. Jennings et al., "Marine aerosol chemistry gradients: elucidating primary and secondary processes and fluxes," Geophysical Research Letters, vol. 35, no. 7, Article ID L07804, 2008.

[26] D. C. Blanchard and A. H. Woodcock, "Bubble formation and modification in the sea and its meteorological significance," Tellus, vol. 9, pp. 145-158, 1957.

[27] A. M. Middlebrook, D. M. Murphy, and D. S. Thomson, "Observations of organic material in individual marine particles at Cape Grim during the First Aerosol Characterization Experiment (ACE I)," Journal of Geophysical Research D, vol. 103, no. 13, pp. 16475-16483, 1998.

[28] C. Leck and E. K. Bigg, "Source and evolution of the marine aerosol-a new perspective," Geophysical Research Letters, vol. 32, no. 19, Article ID L19803, pp. 1-4, 2005.

[29] C. Leck and E. K. Bigg, "Biogenic particles in the surface microlayer and overlaying atmosphere in the central Arctic Ocean during summer," Tellus, Series B, vol. 57, no. 4, pp. 305316, 2005.

[30] B. Bonsang, C. Polle, and G. Lambert, "Evidence for marine production of isoprene," Geophysical Research Letters, vol. 19, no. 11, pp. 1129-1132, 1992.

[31] S. L. Shaw, S. W. Chisholm, and R. G. Prinn, "Isoprene production by Prochlorococcus, a marine cyanobacterium, and other phytoplankton," Marine Chemistry, vol. 80, no. 4, pp. 227-245, 2003.
[32] N. Meskhidze and A. Nenes, "Phytoplankton and cloudiness in the southern ocean," Science, vol. 314, no. 5804, pp. 14191423, 2006.

[33] N. Yassaa, I. Peeken, E. Zöllner et al., "Evidence for marine production of monoterpenes," Environmental Chemistry, vol. 5, no. 6, pp. 391-401, 2008.

[34] G. Luo and F. Yu, "A numerical evaluation of global oceanic emissions of $\alpha$-pinene and isoprene," Atmospheric Chemistry and Physics, vol. 10, no. 4, pp. 2007-2015, 2010.

[35] C. Leck and E. K. Bigg, "Comparison of sources and nature of the tropical aerosol with the summer high Arctic aerosol," Tellus, Series B, vol. 60, no. 1, pp. 118-126, 2008.

[36] W. C. Keene, H. Maring, J. R. Maben et al., "Chemical and physical characteristics of nascent aerosols produced by bursting bubbles at a model air-sea interface," Journal of Geophysical Research D, vol. 112, no. 21, Article ID D21202, 2007.

[37] M. C. Facchini, M. Rinaldi, S. Decesari et al., "Primary submicron marine aerosol dominated by insoluble organic colloids and aggregates," Geophysical Research Letters, vol. 35, no. 17, Article ID L17814, 2008.

[38] S. R. Zorn, F. Drewnick, M. Schott, T. Hoffmann, and S. Borrmann, "Characterization of the South Atlantic marine boundary layer aerosol using an aerodyne aerosol mass spectrometer," Atmospheric Chemistry and Physics, vol. 8, no. 16, pp. 4711-4728, 2008.

[39] D. Hegg, L. Radke, and P. Hobbs, "Measurements of Aitken nuclei and cloud condensation nuclei in the marine atmosphere and their relationship to the DMS-cloud-climate hypothesis," Journal of Geophysical Research, vol. 96, pp. 18727-18733, 1991.

[40] M. O. Andreae, W. Elbert, and S. J. de Mora, "Biogenic sulfur emissions and aerosols over the tropical South Atlantic. 3. Atmospheric dimethylsulfide, aerosols and cloud condensation nuclei," Journal of Geophysical Research, vol. 100, no. 6, pp. 335-356, 1995.

[41] P. G. Falkowski, Y. Kim, Z. Kolber, C. Wilson, C. Wirick, and R. Cess, "Natural versus anthropogenic factors affecting lowlevel cloud albedo over the North Atlantic," Science, vol. 256, no. 5061, pp. 1311-1313, 1992.

[42] R. Boers, G. P. Ayers, and J. L. Gras, "Coherence between seasonal cycles in satellite observed cloud optical depth and boundary layer CCN concentration at a mid-latitude Southern Hemispheric site," Tellus, Series B, vol. 46, pp. 123-131, 1994.

[43] R. Boers, J. R. Acarreta, and J. L. Gras, "Satellite monitoring of the first indirect aerosol effect: retrieval of the droplet concentration of water clouds," Journal of Geophysical Research D, vol. 111, no. 22, Article ID D22208, 2006.

[44] S. M. Vallina, R. Simó, and S. Gassó, "What controls CCN seasonality in the Southern Ocean? A statistical analysis based on satellite-derived chlorophyll and CCN and modelestimated $\mathrm{OH}$ radical and rainfall," Global Biogeochemical Cycles, vol. 20, no. 1, Article ID GB1014, 2006.

[45] Y. Hu, M. Vaughan, C. McClain et al., "Global statistics of liquid water content and effective number concentration of water clouds over ocean derived from combined CALIPSO and MODIS measurements," Atmospheric Chemistry and Physics, vol. 7, no. 12, pp. 3353-3359, 2007.

[46] M. G. Lawrence, "An empirical analysis of the strength of the phytoplankton- dimethylsulfide-cloud-climate feedback cycle," Journal of Geophysical Research, vol. 98, no. 11, pp. 663673, 1993. 
[47] G. J. Roelofs, "A GCM study of organic matter in marine aerosol and its potential contribution to cloud drop activation," Atmospheric Chemistry and Physics, vol. 8, no. 3, pp. 709-719, 2008.

[48] M. A. Miller and S. E. Yuter, "Lack of correlation between chlorophyll a and cloud droplet effective radius in shallow marine clouds," Geophysical Research Letters, vol. 35, no. 13, Article ID L13807, 2008.

[49] J. V. Martins, D. Tanré, L. Remer, Y. Kaufman, S. Mattoo, and R. Levy, "MODIS cloud screening for remote sensing of aerosols over oceans using spatial variability," Geophysical Research Letters, vol. 29, no. 12, Article ID 8009, 2002.

[50] B.-C. Gao, Y. J. Kaufman, D. Tanre, and R.-R. Li, “Distinguishing tropospheric aerosols from thin cirrus clouds for improved aerosol retrievals using the ratio of $1.38-\mu \mathrm{m}$ and $1.24-\mu \mathrm{m}$ channels," Geophysical Research Letters, vol. 29, no. 18, Article ID 1890, 2002.

[51] J. I. Brennan, Y. J. Kaufman, I. Koren, and R. R. Li, “Aerosolcloud interaction-misclassification of MODIS clouds in heavy aerosol," IEEE Transactions on Geoscience and Remote Sensing, vol. 43, no. 4, pp. 911-915, 2005.

[52] Y. J. Kaufman, I. Koren, L. A. Remer, D. Rosenfeld, and Y. Rudich, "The effect of smoke, dust, and pollution aerosol on shallow cloud development over the Atlantic Ocean," Proceedings of the National Academy of Sciences of the United States of America, vol. 102, no. 32, pp. 11207-11212, 2005.

[53] J. Zhang, J. S. Reid, and B. N. Holben, "An analysis of potential cloud artifacts in MODIS over ocean aerosol optical thickness products," Geophysical Research Letters, vol. 32, no. 15, Article ID L15803, 2005.

[54] A. Marshak, S. Platnick, T. Varnai, G. Wen, and R. F. Cahalan, "Impact of 3D radiative effects on satellite retrievals of cloud droplet sizes," Journal of Geophysical Research, vol. 111, Article ID D09207, 2006.

[55] G. Wen, A. Marshak, R. F. Cahalan, L. A. Remer, and R. G. Kleidman, "3D aerosol-cloud radiative interaction observed in collocated MODIS and ASTER images of cumulus cloud fields," Journal of Geophysical Research, vol. 112, Article ID D13204, 2007.

[56] J. L. Tackett and L. Di Girolamo, "Enhanced aerosol backscatter adjacent to tropical trade wind clouds revealed by satellitebased lidar," Geophysical Research Letters, vol. 36, no. 14, Article ID L14804, 2009.

[57] A. Smirnov, B. N. Holben, T. F. Eck, O. Dubovik, and I. Slutsker, "Effect of wind speed on columnar aerosol optical properties at Midway Island," Journal of Geophysical Research D, vol. 108, no. 24, Article ID 4802, 2003.

[58] J. P. Mulcahy, C. D. O’Dowd, S. G. Jennings, and D. Ceburnis, "Significant enhancement of aerosol optical depth in marine air under high wind conditions," Geophysical Research Letters, vol. 35, no. 16, Article ID L16810, 2008.

[59] P. Glantz, E. D. Nilsson, and W. von Hoyningen-Huene, "Estimating a relationship between aerosol optical thickness and surface wind speed over the ocean," Atmospheric Research, vol. 92, no. 1, pp. 58-68, 2009.

[60] N. Bellouin, O. Boucher, J. Haywood, and M. S. Reddy, "Global estimate of aerosol direct radiative forcing from satellite measurements," Nature, vol. 438, no. 7071, pp. 1138-1141, 2005.

[61] B. M. Uz and J. A. Yoder, "High frequency and mesoscale variability in SeaWiFS chlorophyll imagery and its relation to other remotely sensed oceanographic variables," Deep-Sea Research Part II, vol. 51, no. 10-11, pp. 1001-1017, 2004.
[62] Y. Lehahn, I. Koren, E. Boss, Y. Ben-Ami, and O. Altaratz, "Estimating the maritime component of aerosol optical depth and its dependency on surface wind speed using MODIS and QuikSCAT data," Atmospheric Chemistry and Physics Discussions, vol. 10, no. 1, pp. 1983-2003, 2010.

[63] P. W. Boyd, T. Jickells, C. S. Law et al., "Mesoscale iron enrichment experiments 1993-2005: synthesis and future directions," Science, vol. 315, no. 5812, pp. 612-617, 2007.

[64] Y. J. Kaufman, D. Tanré, and O. Boucher, "A satellite view of aerosols in the climate system," Nature, vol. 419, no. 6903, pp. 215-223, 2002.

[65] Y. J. Kaufman, O. Boucher, D. Tanré, M. Chin, L. A. Remer, and T. Takemura, "Aerosol anthropogenic component estimated from satellite data," Geophysical Research Letters, vol. 32, no. 17, Article ID L17804, 2005.

[66] R. E. Korb, M. J. Whitehouse, and P. Ward, "SeaWiFS in the southern ocean: spatial and temporal variability in phytoplankton biomass around South Georgia," Deep-Sea Research Part II, vol. 51, no. 1-3, pp. 99-116, 2004.

[67] N. Meskhidze, A. Nenes, W. L. Chameides, C. Luo, and N. Mahowald, "Atlantic Southern Ocean productivity: fertilization from above or below?" Global Biogeochemical Cycles, vol. 21, no. 2, Article ID GB2006, 2007.

[68] J. H. Martin and S. E. Fitzwater, "Iron-deficiency limits phytoplankton growth in the north-east pacific subarctic," Nature, vol. 331, no. 6154, pp. 341-343, 1988.

[69] P. W. Boyd, A. J. Watson, C. S. Law et al., "A mesoscale phytoplankton bloom in the polar Southern Ocean stimulated by iron fertilization," Nature, vol. 407, no. 6805, pp. 695-702, 2000.

[70] M. P. Meredith, J. L. Watkins, E. J. Murphy, et al., "An anticyclonic circulation above the Northwest Georgia Rise, Argentina," Geophysical Research Letters, vol. 30, no. 2061, p. 5, 2003.

[71] S. T. Gille, "Statistical characterization of zonal and meridional ocean wind stress," Journal of Atmospheric and Oceanic Technology, vol. 22, no. 9, pp. 1353-1372, 2005.

[72] M. T. Woodhouse, G. W. Mann, K. S. Carslaw, and O. Boucher, "New directions: the impact of oceanic iron fertilisation on cloud condensation nuclei," Atmospheric Environment, vol. 42, no. 22, pp. 5728-5730, 2008.

[73] I. E. Galbally, S. J. Lawson, I. A. Weeks et al., "Volatile organic compounds in marine air at Cape Grim, Australia," Environmental Chemistry, vol. 4, no. 3, pp. 178-182, 2007.

[74] X. Yuan, "High-wind-speed evaluation in the Southern Ocean," Journal of Geophysical Research D, vol. 109, no. 13, Article ID D13101, 2004.

[75] P. Vaattovaara, P. E. Huttunen, Y. J. Yoon et al., "The composition of nucleation and Aitken modes particles during coastal nucleation events: evidence for marine secondary organic contribution," Atmospheric Chemistry and Physics, vol. 6, no. 12, pp. 4601-4616, 2006.

[76] R. L. Modini, Z. D. Ristovski, G. R. Johnson et al., "New particle formation and growth at a remote, sub-tropical coastal location," Atmospheric Chemistry and Physics, vol. 9, no. 19, pp. 7607-7621, 2009.

[77] T. F. Eck, B. N. Holben, J. S. Reid et al., "Wavelength dependence of the optical depth of biomass burning, urban, and desert dust aerosols," Journal of Geophysical Research D, vol. 104, no. 24, pp. 31333-31349, 1999.

[78] L. A. Remer, Y. J. Kaufman, D. Tanré et al., "The MODIS aerosol algorithm, products, and validation," Journal of the Atmospheric Sciences, vol. 62, no. 4, pp. 947-973, 2005. 
[79] H. Claustre and S. Maritorena, "The many shades of ocean blue," Science, vol. 302, no. 5650, pp. 1514-1515, 2003.

[80] C. D. O'Dowd, B. Langmann, S. Varghese, C. Scannell, D. Ceburnis, and M. C. Facchini, "A combined organic-inorganic sea-spray source function," Geophysical Research Letters, vol. 35, no. 1, Article ID L07804, 2008.

[81] D. Ceburnis, C. D. O’Dowd, G. S. Jennings et al., "Marine aerosol chemistry gradients: elucidating primary and secondary processes and fluxes," Geophysical Research Letters, vol. 35, no. 7, Article ID L07804, 2008.

[82] L. M. Russell, L. N. Hawkins, A. A. Frossard, P. K. Quinn, and T. S. Bates, "Carbohydrate-like composition of submicron atmospheric particles and their production from ocean bubble bursting," Proceedings of the National Academy of Sciences of the United States of America, vol. 107, no. 15, pp. 6652-6657, 2010.

[83] D. Hansell, C. A. Carlson, D. J. Repeta, and R. Schlitzer, "Dissolved organic matter in the ocean: a controversy stimulates new insights," Oceanography, vol. 22, no. 4, pp. 202-211, 2009.

[84] I. Koren, G. Feingold, and L. A. Remer, "The invigoration of deep convective clouds over the Atlantic: aerosol effect, meteorology or retrieval artifact?" Atmospheric Chemistry and Physics Discussions, vol. 10, no. 2, pp. 3893-3936, 2010.

[85] R. C. Levy, L. A. Remer, D. Tanré et al., "Evaluation of the moderate-resolution imaging spectroradiometer (MODIS) retrievals of dust aerosol over the ocean during PRIDE," Journal of Geophysical Research D, vol. 108, no. 8594, 2003.

[86] C. Cox and W. Munk, "Measurements of the roughness of the sea surface from photographs of the sun's glitter," Journal of the Optical Society of America, vol. 44, pp. 838-850, 1954.

[87] P. Koepke, "Effective reflectance of oceanic whitecaps," Applied Optics, vol. 23, no. 11, pp. 1816-1824, 1984. 

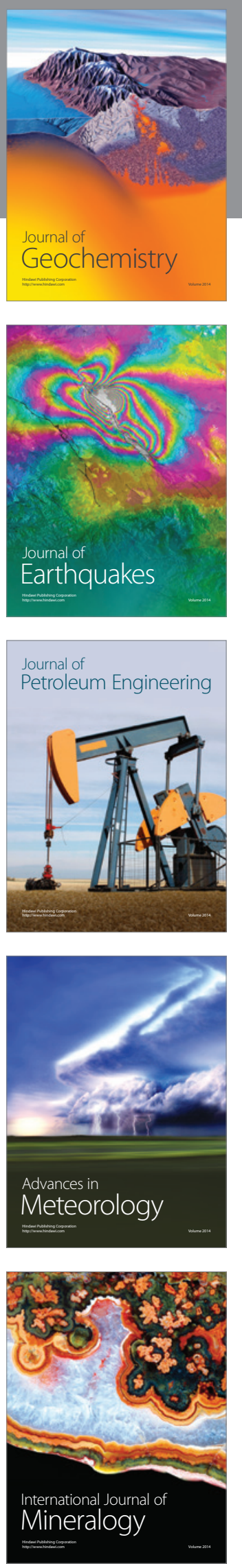
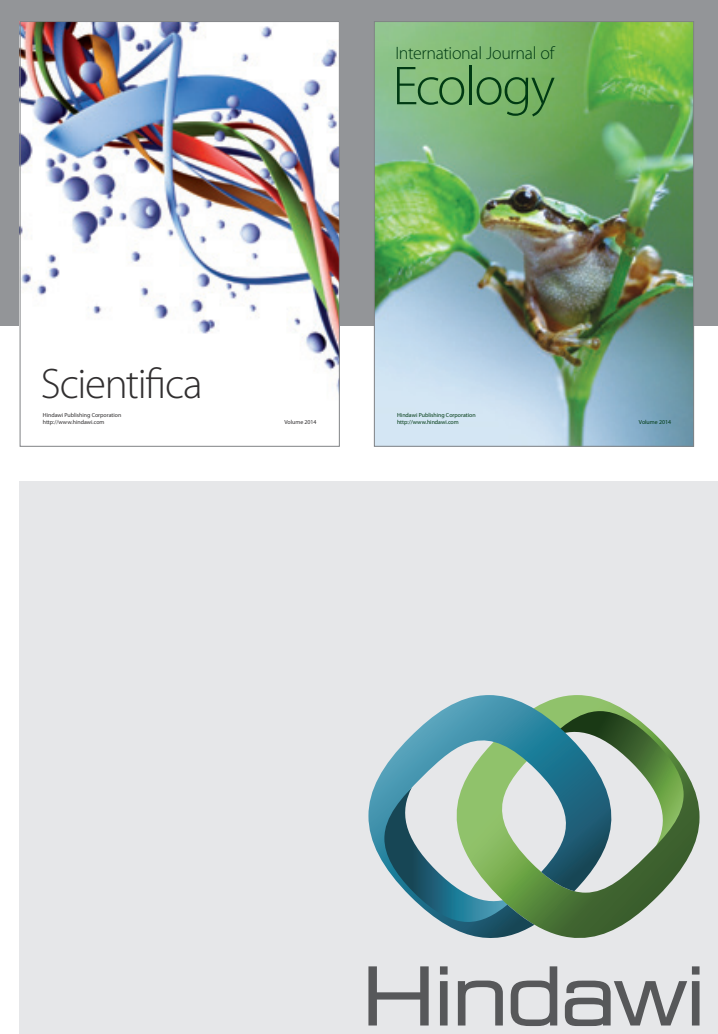

Submit your manuscripts at http://www.hindawi.com
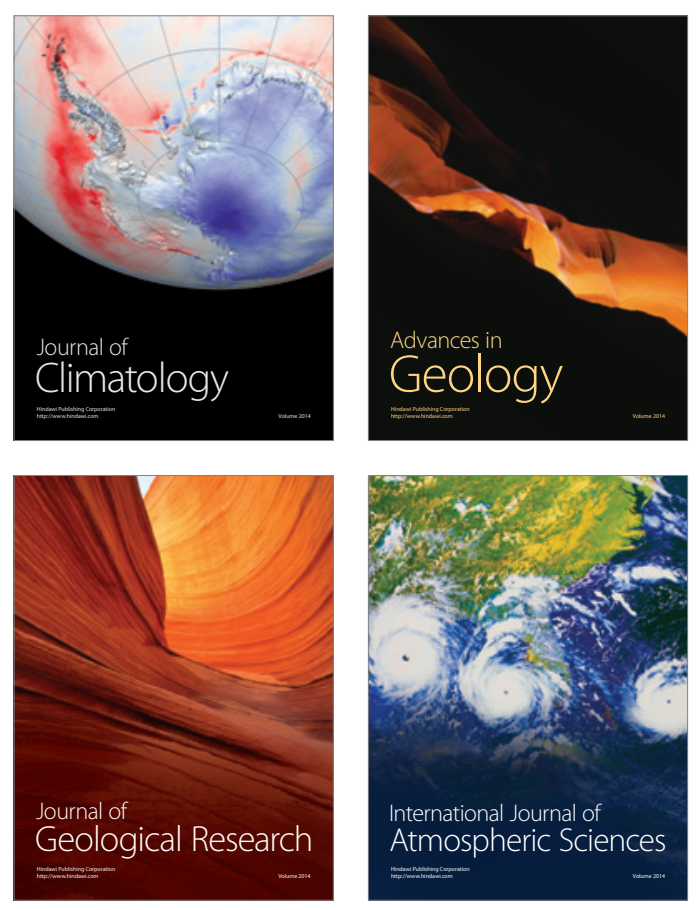
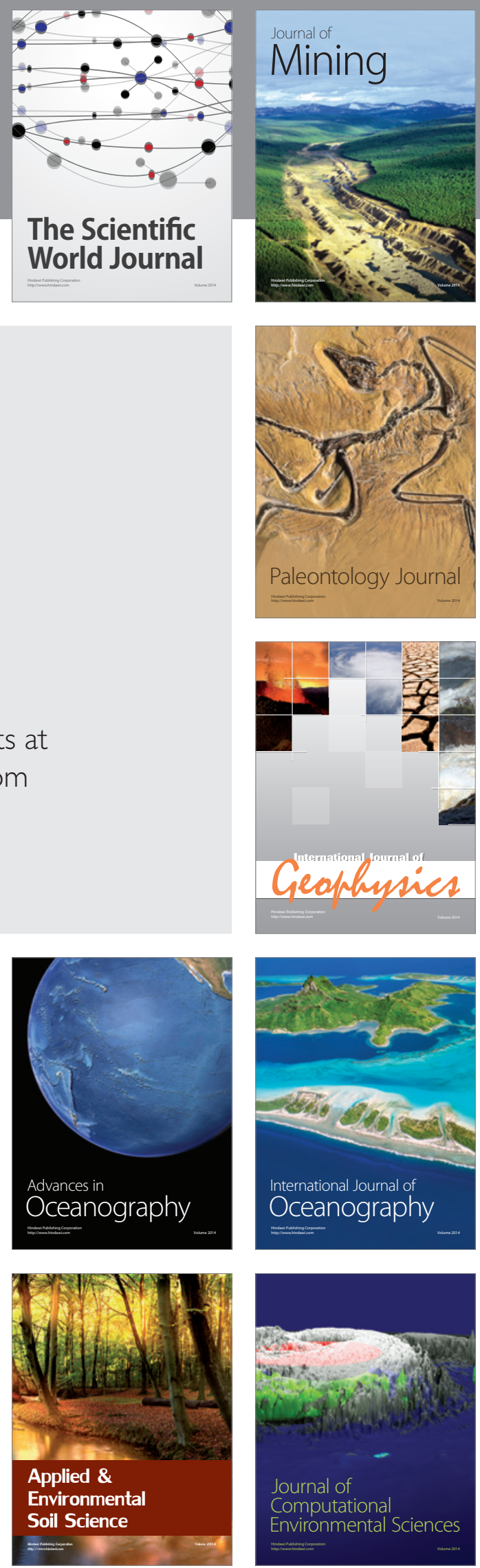